\title{
ВЛИЯНИЕ НОРМЫ ВЫСЕВА НА СЕМЕННУЮ ПРОДУКТИВНОСТЬ ЛЮЦЕРНЫ ГИБРИДНОЙ В УСЛОВИЯХ КРАСНОЯРСКОЙ ЛЕСОСТЕПИ
}

\author{
L.P. Baykalova, T.S. Vlasova, E.V. Kovalenko
}

\section{THE INFLUENCE OF THE NORM OF SEEDING ON SEED EFFICIENCY OF HYBRID ALFALFA IN THE CONDITIONS OF KRASNOYARSK FOREST-STEPPE}

Байкалова Л.П. - д-р с.-х. наук, проф. каф. растениеводства, селекции и семеноводства Красноярского государственного аграрного университета, г. Красноярск.

E-mail: kos.69@mail.ru

Власова T.C. - асп. каф. растениеводства, селекции и семеноводства Красноярского государственного аграрного университета, г. Красноярск. E-mail: vlasovat93@mail.ru

Коваленко Е.В. - студ. 3-го курса Красноярского государственного аграрного университета, г. Красноярск.

E-mail: starm84u@gmail.com

Цель - выявить влияние нормы высева на семенную продуктивность люцерны гибридной. Задачи: определить возможность управления зимостойкостью и сохранностью растений к уборке путем изменения норм высева семян; установить оптимальную структуру стеблестоя, позволяющую наиболее полно реализовывать биологический потенциал культуры; оценить агрофитоценозы люцерны гибридной по количеству семян; определить урожайность семян в зависимости от нормы высева. Методы исследования: закладка опьтов и наблюдения проводились согласно методике ВНИИ кормов и методике государственного сортоиспытания в 2017-2019 г2. В качестве объекта исследования выступили нормы высева люцерны гибридной 5, 10 и 20 ке/2а. Контролем выступала норма высева, рекомендованная для лесостепной зоны Красноярского края при рядовом посеве, - 15 кг/га. По сумме осадков вегетационного периода 2017 2. соответствовал норме, 2018 г. был засушливым, 2019 г. превышал норму. Во все годы распределение осадков было крайне неравномерным: в июне 2018 г. осадков выпало в
Baykalova L.P. - Dr. Agr. Sci., Prof., Chair of Plant Growing, Selection and Seed Farming, Krasnoyarsk State Agrarian University, Krasnoyarsk.

E-mail: kos.69@mail.ru

Vlasova T.S. - Post-Graduate Student, Chair of Plant Growing, Selection and Seed Farming, Krasnoyarsk State Agrarian University, Krasnoyarsk.

E-mail: vlasovat93@mail.ru

Kovalenko E.V. - 3-Year Student, Krasnoyarsk State Agrarian University, Krasnoyarsk.

E-mail: starm84u@gmail.com

1,6 раза меньше нормы, в июне 2019 е. - в 2,3 раза больше. Годы исследований имели более высокую теплообеспеченность в сравнении со средней многолетней величиной. Полевая всхожесть при высеве с нормой 10 кг/га была низкой, максимальное значение (77 \%) было при норме высева 5 ке/га. Число стеблей люцерны зависело от площади питания и погодных условий лет исследований. Зимостойкость в зависимости от нормы высева меняется слабо, она была высокой при 15 кг/га, 5 и 10 кг/га и средней при 20 кг/га. Сохранность растений к уборке в зависимости от нормы высева меняется значительно, лучшую сохранность растений к уборке обеспечивают разреженные посевы, лучшую сохранность стеблей на единице площади - загущенные посевы. Наибольшее количество семян на единице площади получено при высеве с нормой 20 ке/га - 24,55 mыс. um/м². Высев рассматриваемой культуры с разреженными нормами и 10 ке/га тоже обеспечивал прибавки к контролю - 2,85 и 2,03 mыс. шт/M ${ }^{2}$. Получены достоверные прибавки урожайности семян к контролю 15 кг/га при всех изучаемых нормах. 
Посев с нормами 20, 5 и 10 ке/га обеспечивал дополнительный сбор семян 0,77, 0,57 и 0,40 u/га соответственно. Внедрение научных разработок в практику позволяет повысить семенную продуктивность люцерны гибридной на 10-19 \% за счет оптимальной структуры стеблестоя.

Ключевые слова: лющерна гибридная, зимостойкость, число стеблей, количество семян, урожайность семян, норма высева.

The goal was to identify the influence of seeding rate on seed production of hybrid alfalfa. The objectives were to determine the possibility of controlling winter hardiness and safety of the plant for harvest by changing the seeding; to establish optimal structure of the plant stand, allowing them to realize biological potential of culture absolutely; to assess the agrophytocenoses of alfalfa hybrid quantity of seed; determining seed yield depending on seeding rate. The research methods were the experiments and observations carried out according to the methodology of the Institute of Forages and the methodology of the state variety testing in 2017-2019. The norms of seeding of hybrid alfalfa 5, 10 and 20 $\mathrm{kg} / \mathrm{hectare}$ acted as the object of the research. The control was seeding rate recommended for the forest-steppe zone of Krasnoyarsk Region with ordinary sowing - $15 \mathrm{~kg} / \mathrm{hectare}$. According to the amount of precipitation of vegetative period, 2017 corresponded to the norm, 2018 was dry and 2019 exceeded the norm. In all the years the distribution of precipitation was extremely uneven: in June 2018 the precipitation was 1.6 times less than the norm, in June 2019 - 2.3 times more. The years of the research had higher heat supply in comparison with the average long-term value. Field germination at seeding rate of $10 \mathrm{~kg} / \mathrm{hectare}$ was low; the maximum value of $77 \%$ was seeding rate of 5 $\mathrm{kg} / \mathrm{hectare}$. The number of alfalfa stems depended on the area of nutrition and weather conditions of the years of the research. Winter hardiness varied slightly depending on the seeding rate, it was high at $15 \mathrm{~kg} / \mathrm{hectare}, 5 \mathrm{~kg} / \mathrm{hectare}$ and $10 \mathrm{~kg} / \mathrm{hectare}$ and average at $20 \mathrm{~kg} / \mathrm{hectare}$. The safety of plants for harvesting varied significantly depending on the seeding rate, the best safety of plants for harvesting was provided by sparse crops, the best safety of stems per unit area - thickened crops. The largest number of seeds per unit area was obtained when sowing with the norm of $20 \mathrm{~kg} /$ hectare 24.55 thousand pieces $/ \mathrm{m}^{2}$. Sowing of the consid- ered culture with sparse norms of $5 \mathrm{~kg} /$ hectare and $10 \mathrm{~kg} / \mathrm{hectare}$ also provided an increase to the control - 2.85 thousand pieces $/ \mathrm{m}^{2}$ and 2.03 thousand pieces $/ \mathrm{m}^{2}$. Significant increases in seed yield to the control of $15 \mathrm{~kg} / \mathrm{hectare}$ were obtained for all studied norms. Sowing with the norms of 20 $\mathrm{kg} / \mathrm{hectare}, 5 \mathrm{~kg} / \mathrm{hectare}$ and $10 \mathrm{~kg} / \mathrm{hectare}$ provided additional seed collection of $0.77 \mathrm{c} /$ hectare, $0.57 \mathrm{c} /$ hectare and $0.40 \mathrm{c} /$ hectare. The introduction of scientific developments in practice allows increasing seed productivity of alfalfa hybrid by 10 $19 \%$ due to optimal stem structure.

Keywords: alfalfa hybrid, winter hardiness, stems' number, seeds quantity, seed yield, seeding rate.

Введение. Люцерна гибридная (изменчивая) применяется как компонент травосмеси для корма животных в виде зеленой массы, сена, сенажа, в качестве пастбищной культуры. Она отличается высокой питательностью (в 1 кг сухого вещества люцерны содержится 0,79 корм. ед. в фазу бутонизации, 0,53 корм. ед. - в фазу цветения, 0,51 корм. ед. - в фазу обсеменения) и высоким содержанием переваримого протеина $(18,8 \%, 15,4$ и 13,4 \% в бутонизацию, цветение и обсеменение соответственно) [3, 14]. В 1 кг сена содержится 0,4-0,6 корм. ед., 9 \% переваримого протеина в зеленой массе и $20 \%$ в листьях, люцерна изменчивая богата витаминами $\mathrm{A}, \mathrm{B}_{1}, \mathrm{~B}_{2}, \mathrm{C}, \mathrm{Z}, \mathrm{E}, \mathrm{K}, \mathrm{P}$, солями кальция, фоссрора, микроэлементами и незаменимыми аминокислотами [4, 12, 18, 20-22, 28]. По различным оценкам, в Сибири на долю люцерны гибридной, включая смешанные посевы, приходится 30-60 \% посевов многолетних бобовых трав $[6,23,27]$.

Н.Г. Ведров, Ю.Г. Лазарев [5] отмечали в качестве основных задач интенсификации сельскохозяйственного производства Красноярского края ускоренное внедрение в производство высокоурожайных сортов и хорошую организацию семеноводства. К сожалению, отрицательные тенденции в семеноводстве (снижение удельного веса сортовых посевов, сокращение площадей под новыми сортами, ухудшение материально-технической базы семеноводства), о которых говорили вышеупомянутые авторы, актуальны и сегодня как в Красноярском крае, так и в целом по России $[1,11,15,19]$. Наукой установлено и практика подтверждает, что высококачественные семена обеспечивают около $20 \%$ 
прироста продукции [6]. Основной причиной ухудшения кормовой базы является разрушение системы семеноводства многолетних трав [17].

По вопросу влияния нормы высева на семенную продуктивность люцерны гибридной существуют различные мнения. Так, в условиях Среднего Поволжья люцерну на зеленую массу высевали с нормой $15 \mathrm{kr} / г \mathrm{a}$, на семена 6 кг/га [10], на Урале коэфффициент высева люцерны варьировал в широких пределах и составлял от 0,83 до 9,0 млн всх. семян/га [24, 25]. В Центральном Нечерноземье России на мелиорированных землях норма высева люцерны составляла 8 кг/га [13].

Существующее положение вещей делает актуальной представленную тему. Исходя из этих посылов, мы провели опыты с люцерной изменчивой при ее возделывании с различными нормами высева.

Цель работы. Выявить влияние нормы высева на семенную продуктивность люцерны изменчивой.

Задачи: определить возможность управления зимостойкостью и сохранностью растений к уборке путем изменения норм высева семян; установить оптимальную структуру стеблестоя, позволяющую наиболее полно реализовывать биологический потенциал культуры; оценить агрофитоценозы люцерны гибридной по количеству семян; определить урожайность семян в зависимости от нормы высева.

Методы исследования. Полевые исследования проводились в лесостепной зоне на опытном поле кафедры растениеводства и плодоовощеводства в УНПК «Борский» Сухобузимского района Красноярского края. Почва опытного участка представлена черноземом выщелоченным, среднесуглинистая по гранулометрическому составу с содержанием гумуса в пахотном слое 5,0-6,8 \%, среднеобеспеченная по содержанию основных элементов питания, $\mathrm{pH}=6,5-6,8$. Предшественник - черный пар. Обработка почвы осуществлялась согласно общепринятым рекомендациям для данной зоны (зяблевое глубокое рыхление, три культивации в течение весенне-летнего периода, предпосевная обработка).

Закладка опыта проводилась в 2017 г. 19 июля перед массовым выпадением осадков, что является оптимальным для Красноярской лесостепи. Площадь делянки - 76,8 м² (6,4 м × 12 м), повторность - четырехкратная, размещение методом систематических повторений. Способ посева - рядовой (15 ×15 см), сеялкой ССНП-1,6. Учет урожайности проведен в 2018, 2019 гг.

Закладка опытов и наблюдения проводились согласно методике ВНИИ кормов им. В.Р. Вильямса [16], методике селекции кормовых трав в Сибири [7] и методике государственного сортоиспытания [26]. Статистическая обработка результатов проведена по методикам Б.А. Доспехова [9]. Для исследования были выбраны нормы высева люцерны гибридной - 5 кг/га; 10; 15 и 20 кг/га, при фрактической хозяйственной годности они составили 6,1 кг/га; 12,2; 18,3 и 24,4 кг/га (табл. 1). Контролем являлась норма высева, рекомендованная при рядовом посеве для лесостепной зоны, - 15 кг/га [19]. Использовали сорт люцерны гибридной Деметра, включенный в Государственный реестр селекционных достижений, допущенных к использованию на территории Красноярского края в 2015 г. по зоне Канско-Красноярской лесостепи [8].

Таблица 1

\section{Расчет нормы высева люцерны гибридной при фактической хозяйственной годности (ХГ)}

\begin{tabular}{|c|c|c|c|c|c|}
\hline \multirow{2}{*}{$\begin{array}{l}\text { Норма высева, } \\
\text { кг/га }\end{array}$} & \multirow{2}{*}{$\begin{array}{c}\text { Хозяйственная } \\
\text { годность семян } \\
(Х Г), \\
\% \\
\end{array}$} & \multicolumn{2}{|c|}{$\begin{array}{c}\text { Норма высева в чистом } \\
\text { посеве, кг/га }\end{array}$} & \multirow{2}{*}{$\begin{array}{l}\text { Коэффрици- } \\
\text { ент } \\
\text { высева, } \\
\text { млн шт/га } \\
\end{array}$} & \multirow{2}{*}{$\begin{array}{l}\text { Ориентировочное коли- } \\
\text { чество семян на } 1 \text { пог. } \\
\text { метр рядка при межд-- } \\
\text { рядье } 15 \text { см }\end{array}$} \\
\hline & & $\begin{array}{c}\text { при } \\
100 \%-и ̆ X \Gamma\end{array}$ & $\begin{array}{c}\text { при фракт. } \\
\text { ХГ }\end{array}$ & & \\
\hline 15 (контроль) & 82 & 15 & 18,3 & 7,0 & 105 \\
\hline 5 & 82 & 5 & 6,1 & 2,5 & 38 \\
\hline 10 & 82 & 10 & 12,2 & 5,0 & 75 \\
\hline 20 & 82 & 20 & 24,4 & 10,0 & 150 \\
\hline
\end{tabular}


Характеристика погодных условий была сделана по данным Архива погоды в Сухобузимском районе [2]. Климат зоны Красноярской лесостепи резко континентальный. Анализируя показатели за 2017-2019 гг., можно отметить, что погодные условия существенно отличались от среднемноголетних данных (рис. 1). В мае и июне 2017 г. выпало 26 и 20 мм осадков, что соответсвует 74,9 и 57,6 \% от среднемноголетней суммы осадков. Из-за малого количества осадков почвенный слой несколько иссушился, однако в июле недостаток влаги был восполнен: количество осадков превышало норму на 8,5 мм, среднесуточная температура июля соответствовала норме, что позволило многолетним бобовым травам дать дружные всходы. В августе и сентябре была теплая погода, с сильными дождями, за два месяца выпало 160 мм осадков, что способствовало хорошему росту и развитию трав. Вегетационный период 2017 г. можно охарактеризовать как благоприятный для выращивания люцерны.

Погодные условия 2018 г. отличались высокими среднесуточными температурами и недостатком осадков, с мая по сентябрь выпало 149 мм, что составляет 60,3 \% от средней многолетней величины (рис. 1). Май 2018 г. был жарким $\left(14,9^{\circ} \mathrm{C}\right)$ и засушливым (11 мм). В июне температурный фон был повышен, среднесуточная температура составляла $20,6{ }^{\circ} \mathrm{C}$, когда среднемноголетнее значение равно $15,5^{\circ} \mathrm{C}$, условия увлажнения были засушливыми (29 мм осадков при норме 46,8 мм). Среднесуточная температура июля соответсвовала норме, количество осадков было вдвое ниже ее. В августе наблюдалась жесткая почвенная и воздушная засуха. Среднесуточная температура составляла $18,4{ }^{\circ} \mathrm{C}$, количество осадков 21 мм. Вегетационный период 2018 г. можно охарактеризовать как крайне неблагоприятный для растений многолетних бобовых трав.

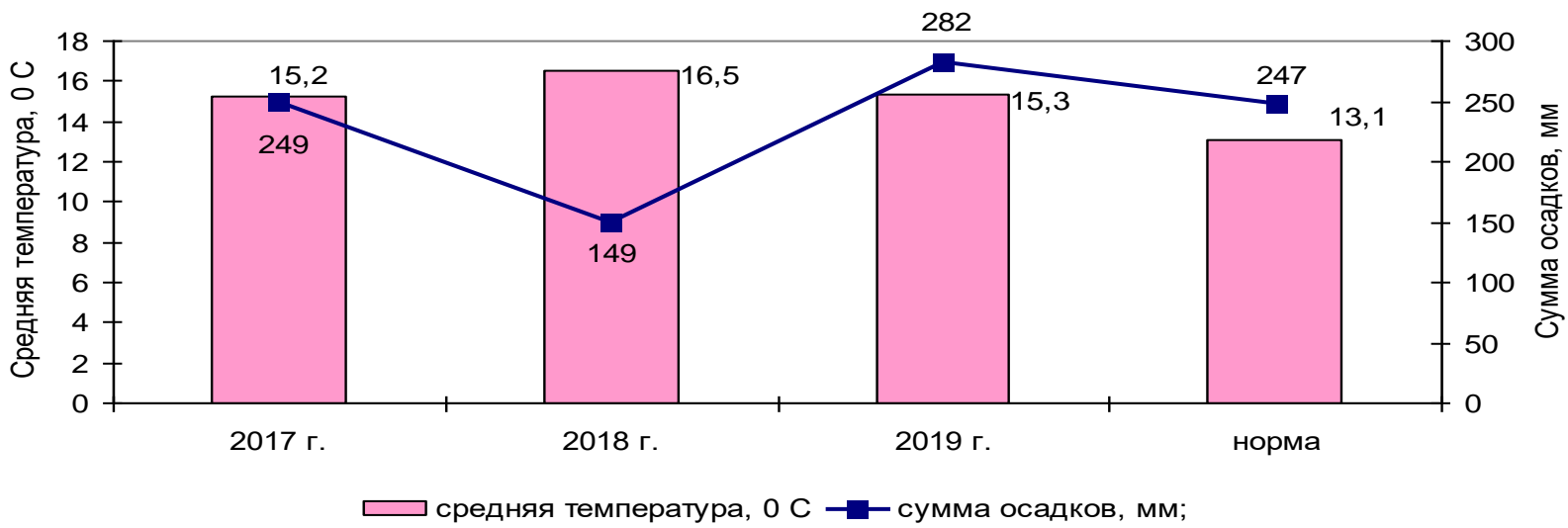

Pис. 1. Метеорологическая характеристика вегетационного периода Сухобузимского района (май - сентябрь)

Погодные условия 2019 г. отличались повышенными среднесуточными температурами и неравномерным распределением осадков, с мая по сентябрь выпало 282 мм, что составляет $114,2 \%$ от средней многолетней величины (см. рис. 1). Май 2019 г. был теплым $\left(9,7^{\circ} \mathrm{C}\right)$ и засушливым (8,3 мм). В июне, июле, августе и сентябре температурный фон был повышен, среднесуточная температура составляла $18,7^{\circ} \mathrm{C} ; 19,5 ; 18,7 ; 18,9 ; 9,9^{\circ} \mathrm{C}$ соответственно, что выше среднемноголетнего значения на 1,6 $4,0^{\circ} \mathrm{C}$. Распределение осадков по месяцам ве- гетационного периода 2019 г. было крайне неравномерным: в июне, августе и сентябре их количество превышало норму. В августе и сентябре - в 1,2; 1,3 раза, особенно значительно в июне - в 2,3 раза. Количество выпавших осадков в июле составляло 45 мм при норме 64,5 мм. В целом 2019 год по тепло- и влагообеспеченности превышал норму и относился к умеренно увлажненным (см. рис. 1).

Результаты и их обсуждение. Важной характеристикой адаптации вида или сорта является полевая всхожесть семян, интенсивность 
изреживания травостоя в процессе вегетации и сохранность растений в зимний период. Несмотря на то что посев был осуществлен одинаковыми семенами, полевая всхожесть в зависимости от нормы высева существенно различалась. Низкой она была при высеве с нормой 10 кг/га, максимальное значение (77 \%) было при норме высева 5 кг/га (табл. 2). Число растений после перезимовки достоверно отличалось от контроля: меньшее количество растений отмечено при нормах высева 5 и 10 кг/га и боль- шее - при 20 кг/га. Более высокая зимостойкость формировалась в разреженных посевах (5 и $10 \mathrm{kr} / \mathrm{ra}$ ), а также при норме высева $15 \mathrm{kr/га.}$ Повышение нормы высева люцерны приводило к снижению ее зимостойкости. Зимостойкость люцерны при норме высева 20 кг/га была средней - при остальных исследуемых нормах высева - высокой. Сохранность растений к уборке существенно зависела от нормы высева и была максимальной при высеве с нормой 10 кг/га (табл. 2).

Таблица 2

Влияние нормы высева на формирование травостоя люцерны гибридной, 2017, 2018 гг.

\begin{tabular}{|c|c|c|c|c|c|c|}
\hline \multirow{2}{*}{$\begin{array}{c}\text { Норма высева, } \\
\text { кг/га }\end{array}$} & \multicolumn{3}{|c|}{ Число растений, шт/м ${ }^{2}$} & $\begin{array}{c}\text { Полевая } \\
\text { всхожесть, } \\
\%\end{array}$ & $\begin{array}{c}\text { 3имос- } \\
\text { тойкость, } \\
\%\end{array}$ & $\begin{array}{c}\text { Сохран- } \\
\text { ность к } \\
\text { уборке, \% }\end{array}$ \\
\hline 15 (контроль) & 369 & 199 & 154 & 53 & 77 & 42 \\
\hline 5 & 193 & 134 & 109 & 77 & 69 & 56 \\
\hline 10 & 157 & 115 & 97 & 31 & 73 & 62 \\
\hline 20 & 445 & 268 & 214 & 45 & 60 & 48 \\
\hline НСР & 18 & 28 & 21 & & & \\
\hline
\end{tabular}

Число стеблей люцерны зависело от площади питания и погодных условий лет исследований. Число стеблей в фазу весеннего отраста- ния и перед уборкой семян по годам значительно различалось, за исключением нормы высева 20 кг/га в весеннее отрастание (табл. 3).

Таблица 3

Динамика стеблестоя люцерны гибридной при различных нормах высева, шт/м 2

\begin{tabular}{|c|c|c|c|c|c|c|}
\hline \multirow{3}{*}{$\begin{array}{c}\text { Норма высева, } \\
\text { кг/га }\end{array}$} & \multicolumn{6}{|c|}{ Число стеблей, шт/м 2} \\
\hline & \multicolumn{3}{|c|}{ Весеннее отрастание } & \multicolumn{3}{|c|}{ Перед уборкой } \\
\hline & 2018 г. & 2019 г. & Среднее & 2018 г. & 2019 г. & Среднее \\
\hline 15 (контроль) & 498 & 550 & 524 & 385 & 445 & 415 \\
\hline 5 & 349 & 570 & 459 & 283 & 497 & 390 \\
\hline 10 & 413 & 525 & 419 & 243 & 494 & 369 \\
\hline 20 & 622 & 606 & 615 & 556 & 586 & 571 \\
\hline HCP 05 А норма & 36 & 17 & 10 & 10 & 11 & 7 \\
\hline НСР 05 в год & & & 7 & & & 5 \\
\hline $\mathrm{HCP} 05 \mathrm{~A} \times \mathrm{B}$ & & & 14 & & & 10 \\
\hline
\end{tabular}

В 2018 г. достоверно превышала контроль по числу стеблей норма высева 20 кг/га в фазу весеннего отрастания, в 2019 г. - нормы высева 5 и 20 кг/га. Число стеблей к уборке снижалось при всех нормах высева. Больше всего оно снизилось у контроля - на 109 шт/м 2, при норме высева 5 кг/га - на 69 шт/м 2, 10 кг/га - на 50 шт/м 2, 20 кг/га - на 44 шт/м 2 (см. табл. 3).
Превосходили контроль по числу стеблей перед уборкой в среднем за годы исследований лишь загущенные посевы при норме 20 кг/га.

Исследуемые нормы высева достоверно превосходили контроль по количеству семян на квадратный метр как в отдельно взятые годы, так и в среднем. Более высокий вклад отмечен 
в 2019 г. - от 11,84 \% при норме высева 10 кг/га до 22,85 \% при норме высева 20 кг/га (рис. 2).

Сравнительное изучение семенной продуктивности люцерны гибридной при различных нормах высева в условиях лесостепи Краснояр- ского края показало достоверные прибавки количества и урожайности семян к контролю (15 кг/га). Прибавки урожайности семян составили 0,57 ц/га, 0,40 и 0,77 ц/га при нормах высева 5 кг/га, 10 и 20 кг/га соответственно (табл. 4).

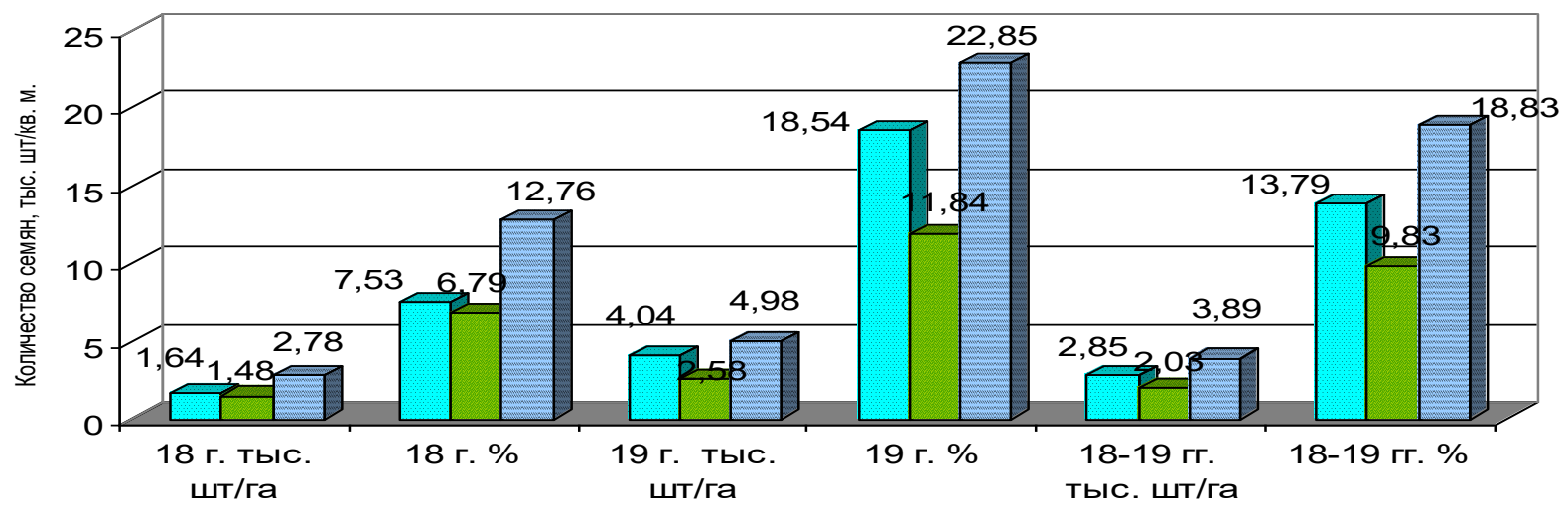

$\square 5$ кг/га; $\square 10$ кг/га; $\boxminus 20$ кг/га

Pис. 2. Вклад нормы высева в рост количества семян люцерны гибридной, 2018 г.: НСР $05-$

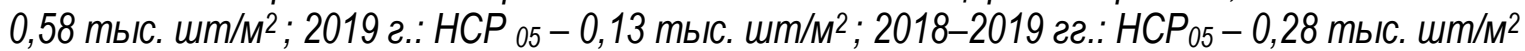

Таблица 4

Семенная продуктивность люцерны гибридной при различных нормах высева, 2018, 2019 гг.

\begin{tabular}{|c|c|c|c|c|c|c|}
\hline \multirow{2}{*}{$\begin{array}{c}\text { Норма высева, } \\
\text { кг/га }\end{array}$} & \multirow{2}{*}{$\begin{array}{c}\text { Количество } \\
\text { семян, тыс. шт/м² }\end{array}$} & \multicolumn{2}{|c|}{ 土 к контролю } & \multirow{2}{*}{$\begin{array}{c}\text { Урожайность } \\
\text { семян, ц/га }\end{array}$} & \multicolumn{2}{|c|}{ 土 к контролю } \\
\hline & & $\begin{array}{c}\text { Tыс. } \\
\text { шт/M² }\end{array}$ & $\%$ & & ц/га & $\%$ \\
\hline 15 (контроль) & 20,66 & & & 4,14 & & \\
\hline 5 & 23,51 & 2,85 & 13,79 & 4,71 & 0,57 & 13,77 \\
\hline 10 & 22,69 & 2,03 & 9,83 & 4,54 & 0,40 & 9,66 \\
\hline 20 & 24,55 & 3,89 & 18,83 & 4,91 & 0,77 & 18,60 \\
\hline HCP 05 А норма & 0,28 & & & 0,13 & & \\
\hline НСР 05 в год & 0,20 & & & 0,09 & & \\
\hline $\mathrm{HCP} 05 \mathrm{~A} \times \mathrm{B}$ & 0,40 & & & 0,18 & & \\
\hline
\end{tabular}

Увеличение количества семян при высеве люцерны с нормами 5 и 10 кг/га связано с большим количеством семян в бобах, а при норме высева $20 \mathrm{\kappa г/га} \mathrm{-} \mathrm{с} \mathrm{большей} \mathrm{численно-}$ стью продуктивных стеблей в сравнении с контролем.

\section{Выводы}

1. Высокая полевая всхожесть люцерны гибридной получена при высеве с нормой 5 кг/га $77 \%$; зимостойкость в зависимости от нормы высева меняется слабо, она была высокой при 
15 кг/га, 5 и 10 кг/га и средней при 20 кг/га. Сохранность растений к уборке в зависимости от нормы высева меняется значительно, лучшую сохранность растений к уборке обеспечивают разреженные посевы, лучшую сохранность стеблей на единице площади - загущенные посевы.

2. В результате проведенных исследований по влиянию нормы высева на семенную продуктивность люцерны гибридной выявлено, что наибольшее количество семян получено при высеве с нормой $20 \mathrm{kr} / г \mathrm{r}-24,55$ тыс. шт/м². Высев рассматриваемой культуры с разреженными нормами 5 и 10 кг/га тоже обеспечивал прибавки к контролю - 2,85 и 2,03 тыс. шт/м 2. Урожайность семян люцерны гибридной зависела от нормы высева. Получены достоверные прибавки урожайности семян к контролю 15 кг/га при всех изучаемых нормах. Посев с нормами 20 кг/га, 5 и 10 кг/га обеспечивал дополнительный сбор семян 0,77 ц/га, 0,57 и 0,40 ц/га.

\section{Литература}

1. Агропромышленный комплекс Красноярского края в 2016 году: информационноаналитический материал. - Красноярск: Format, 2017. - 198 c.

2. Архив погоды в Сухобузимском районе [Электронный ресурc]. - URL: rp5.ru.

3. Байкалова Л.П., Салагашев И.Ю. Оптимизация структуры травосмесей многолетних злаково-бобовых трав среднесрочного сенокосного использования // Международный сельскохозяйственный журнал. - 2015. - № 3. - C. 54-56.

4. Биоклиматология бобовых и злаковых трав: клевер, тимофреевка, люцерна, вика, люпин, овсяница, соя, чина. - Л.: Гидрометеоиздат, 1981. - $128 \mathrm{c}$.

5. Ведров Н.Г., Лазарев Ю.Г. Семеноводство и сортоведение полевых культур Красноярского края. - Красноярск: Изд-во КрасГАУ, 1997. - $138 \mathrm{c}$.

6. Гончаров П.Л. Кормовые культуры Сибири: ботанико-биологические основы возделывания. - Новосибирск: Изд-во Новосиб. унта, 1992. -264 c.

7. Гончаров П.Л. Методика селекции кормовых трав в Сибири. - Новосибирск: ООО «Ревик-К», 2003. - 396 с.
8. Государственный реестр селекционных достижений, допущенных к использованию по Красноярскому краю на 2018 год / Филиал ФГБУ «Госсорткомиссия» по Красноярскому краю, Республике Хакасия и Республике Тыва. - Красноярск, 2018. - 244 с.

9. Доспехов Б.А. Методика полевого опыта (с основами статистической обработки результатов исследований). - Изд. 6-е, перераб. и доп. - М.: Агропромиздат, 2011. $351 \mathrm{c}$.

10. Епифанова И., Тимошкин О., Лапина М. Селекция люцерны для условий лесостепи Среднего Поволжья // Международный сельскохозяйственный журнал. - 2016. № 6. - C. 53-56.

11. Косолапов В.М., Трофимов И.А. Состояние и перспективы развития кормопроизводства России в XXI веке // Современное состояние и стратегия развития кормопроизводства в XXI веке: мат-лы междунар. науч.-практ. конф. / Россельхозакадемия, Сиб. отд-ние, СибНИИ кормов. - Новосибирск, 2013. - С. 14-25.

12. Кривоногова Д.В. Оптимизация технологий производства многолетних трав на корма в Красноярской лесостепи: дис. ...канд. с.-х. наук: 06.02.08. - Красноярск, 2018. - 169 с.

13. Ковалев Н.Г., Капсамун А.Д., Павлючик Е.Н. [и др.]. Инновационные кормовые культуры для создания зеленого и сырьевого конвейера на мелиорированных землях Центрального Нечерноземья России // Вестник ВНИИМЖ. - 2017. - № 3 (27). - С. 55-59.

14. Кожухова Е.В. Оценка питательной ценности и технологий производства сенокосных травосмесей в Красноярской лесостепи: дис. ... канд. с.-х. наук: 06.02.08. - Красноярск, 2015. - 143 с.

15. Ледяева Н.В. Эффрективность возделывания люцерны изменчивой в среднегорной зоне Республики Алтай // Вестник Алтайского государственного аграрного университета. - 2016. - № 9. - С. 33-37.

16. Методические указания по проведению полевых опытов с кормовыми культурами / ВНИИК им. В.Р. Вильямса. - М., 1987. - 197 с.

17. Павлова С.А., Пестерева Е.С., Захарова Г.Е. Кормопроизводство в Республике Саха 
(Якутия): состояние и перспективы // Кормопроизводство. - 2018. - № 5. - С. 5-8.

18. Попов И.С. Практические занятия по курсу кормления сельскохозяйственных животных. - М.: Сельхозгиз, 1949. - 93 с.

19. Система земледелия Красноярского края на ландшафттной основе: науч.-практ. рекомендации / под общ. ред. С.В. Брылева. Красноярск: Поликор, 2017. - 224 с.

20. Смелов С.М., Конюшкин Н.С. Многолетние травы в лугопастбищных севооборотах. М.: Сельхозгиз, 1951. - 143 с.

21. Смелов С.М. Теоретические основы луговодства. - М.: Колос, 1966. - 154 с.

22. Соколова О.М. Опыт сортоучастков - всем колхозам и совхозам. - Л.: Лениздат, 1972. $-105 \mathrm{c}$.

23. Степанов А.Ф. Создание и использование многолетних травостоев: монография. Омск: Изд-во ФГОУ ВПО ОмГАУ, 2006. $312 \mathrm{c}$.

24. Тормозин M.A., Нагибин А.Е., Зырянцева А.А. Сравнительное изучение сортообразцов люцерны в условиях Урала // Пермский аграрный вестник. - 2018. - № 3 (23). C. 23-25.

25. Тормозин М.А., Зырянцева А.А. Новые перспективные линии люцерны уральской селекции с комплексом хозяйственно ценных признаков // Зернобобовые и крупяные культуры. - 2019. - № 1 (29). - С. 78-84.

26. Федин М.А. Методика государственного сортоиспытания сельскохозяйственных культур. - М., 1985. - 263 с.

27. Характеристика и особенности агротехники сортов многолетних трав селекции СибНИИСХ: рекомендации / Б.А. Абубекеров, У.М. Сагадбеков. - Новосибирск, 1991. - 52 с.

28. Schwarz R. Einfluss wirtschaftlicher Maßnahmen auf den Pflanzen bestand des Grünlandes /I Lolw. lahrb. - 2013. - № 7. - S. 28-32.

\section{Literatura}

1. Agropromyshlennyj kompleks Krasnojarskogo kraja V 2016 godu: informacionnoanaliticheskij material. - Krasnojarsk: Format, 2017. - $198 \mathrm{~s}$.

2. Arhiv pogody $\mathrm{v}$ Suhobuzimskom rajone [Jelektronnyj resurs]. - URL: rp5.ru.
3. Bajkalova L.P., Salagashev I.Ju. Optimizacija struktury travosmesej mnogoletnih zlakovobobovyh trav srednesrochnogo senokosnogo ispol'zovanija // Mezhdunarodnyj sel'skohozjajstvennyj zhurnal. - 2015. - № 3. - S. 54-56.

4. Bioklimatologija bobovyh i zlakovyh trav: klever, timofeevka, ljucerna, vika, ljupin, ovsjanica, soja, china. - L.: Gidrometeoizdat, 1981. - $128 \mathrm{~s}$.

5. Vedrov N.G., Lazarev Ju.G. Semenovodstvo i sortovedenie polevyh kul'tur Krasnojarskogo kraja. - Krasnojarsk: Izd-vo KrasGAU, 1997. $138 \mathrm{~s}$.

6. Goncharov P.L. Kormovye kul'tury Sibiri: botaniko-biologicheskie osnovy vozdelyvanija. - Novosibirsk: Izd-vo Novosib. un-ta, 1992. $264 \mathrm{~s}$.

7. Goncharov P.L. Metodika selekcii kormovyh trav v Sibiri. - Novosibirsk: 000 «Revik-K», 2003. - $396 \mathrm{~s}$.

8. Gosudarstvennyj reestr selekcionnyh dostizhenij, dopushhennyh $\mathrm{k}$ ispol'zovaniju po Krasnojarskomu kraju na 2018 god / Filial FGBU «Gossortkomissija» po Krasnojarskomu kraju, Respublike Hakasija i Respublike Tyva. - Krasnojarsk, 2018. - $244 \mathrm{~s}$.

9. Dospehov B.A. Metodika polevogo opyta (s osnovami statisticheskoj obrabotki rezul'tatov issledovanij). - Izd. 6-e, pererab. i dop. - M.: Agropromizdat, 2011. - $351 \mathrm{~s}$.

10. Epifanova I., Timoshkin O., Lapina M. Selekcija ljucerny dlja uslovij lesostepi Srednego Povolzh'ja // Mezhdunarodnyj sel'skohozjajstvennyj zhurnal. - 2016. - № 6 . - S. 53-56.

11. Kosolapov V.M., Trofimov I.A. Sostojanie i perspektivy razvitija kormoproizvodstva Rossii v XXI veke // Sovremennoe sostojanie i strategija razvitija kormoproizvodstva $v$ XXI veke: mat-ly mezhdunar. nauch.-prakt. konf. I Rossel'hozakademija, Sib. otd-nie, SibNII kormov. - Novosibirsk, 2013. - S. 14-25.

12. Krivonogova D.V. Optimizacija tehnologij proizvodstva mnogoletnih trav na korma $\mathrm{V}$ Krasnojarskoj lesostepi: dis. ...kand. s.-h. nauk: 06.02.08. - Krasnojarsk, 2018. - 169 s.

13. Kovalev N.G., Kapsamun A.D., Pavljuchik E.N. [i dr.]. Innovacionnye kormovye kul'tury dlja sozdanija zelenogo i syr'evogo konvejera na 
meliorirovannyh zemljah Central'nogo Nechernozem'ja Rossii // Vestnik VNIIMZh. 2017. - № 3 (27). - S. 55-59.

14. Kozhuhova E.V. Ocenka pitatel'noj cennosti i tehnologij proizvodstva senokosnyh travosmesej v Krasnojarskoj lesostepi: dis. ... kand. s.-h. nauk: 06.02.08. - Krasnojarsk, 2015. - $143 \mathrm{~s}$.

15. Ledjaeva N.V. Jeffektivnost' vozdelyvanija ljucerny izmenchivoj $v$ srednegornoj zone Respubliki Altaj // Vestnik Altajskogo gosudarstvennogo agrarnogo universiteta. 2016. - № 9. - S. 33-37.

16. Metodicheskie ukazanija po provedeniju polevyh opytov s kormovymi kul'turami / VNIIK im. V.R. Vil'jamsa. - M., 1987. - 197 s.

17. Pavlova S.A., Pestereva E.S., Zaharova G.E. Kormoproizvodstvo $v$ Respublike Saha (Jakutija): sostojanie i perspektivy // Kormoproizvodstvo. - 2018. - № 5. - S. 5-8.

18. Popov I.S. Prakticheskie zanjatija po kursu kormlenija sel'skohozjajstvennyh zhivotnyh. M.: Sel'hozgiz, 1949. - 93 s.

19. Sistema zemledelija Krasnojarskogo kraja na landshaftnoj osnove: nauch.-prakt. rekomendacii / pod obshh. red. S.V. Bryleva. Krasnojarsk: Polikor, 2017. - $224 \mathrm{~s}$.

20. Smelov S.M., Konjushkin N.S. Mnogoletnie travy $\mathrm{v}$ lugopastbishhnyh sevooborotah. M.: Sel'hozgiz, 1951. - 143 s.
21. Smelov S.M. Teoreticheskie osnovy lugovodstva. - M.: Kolos, 1966. - $154 \mathrm{~s}$.

22. Sokolova O.M. Opyt sortouchastkov - vsem kolhozam i sovhozam. - L.: Lenizdat, 1972. $105 \mathrm{~s}$.

23. Stepanov A.F. Sozdanie i ispol'zovanie mnogoletnih travostoev: monografija. - Omsk: Izd-vo FGOU VPO OmGAU, 2006. - $312 \mathrm{~s}$.

24. Tormozin M.A., Nagibin A.E., Zyrjanceva A.A. Sravnitel'noe izuchenie sortoobrazcov ljucerny v uslovijah Urala // Permskij agrarnyj vestnik. 2018. - № 3 (23). - S. 23-25.

25. Tormozin M.A., Zyrjanceva A.A. Novye perspektivnye linii ljucerny ural'skoj selekcii $\mathrm{s}$ kompleksom hozjajstvenno cennyh priznakov // Zernobobovye i krupjanye kul'tury. 2019. - № 1 (29). - S. 78-84.

26. Fedin M.A. Metodika gosudarstvennogo sortoispytanija sel'skohozjajstvennyh kul'tur. M., 1985. - $263 \mathrm{~s}$.

27. Harakteristika i osobennosti agrotehniki sortov mnogoletnih trav selekcii SibNIISH: rekomendacii / B.A. Abubekerov, U.M. Sagadbekov. Novosibirsk, 1991. - $52 \mathrm{~s}$.

28. Schwarz $R$. Einfluss wirtschaftlicher Maßnahmen auf den Pflanzen bestand des Grünlandes // Lolw. lahrb. - 2013. - № 7. S. 28-32. 